\title{
Influence of Habituation on Self-Awareness and Prosocial Behavior in 4-5-Year-Old Children
}

\author{
Z. Zuhro, W. Sukartiningsih, B.S. Bachri \\ Universitas Negeri Surabaya \\ Surabaya, Indonesia \\ zuhrolukman@gmail.com
}

\begin{abstract}
The aim of this study to determine the habit of self-awareness and prosocial behavior in an early child aged 4-5 years at a kindergarten, Surabaya, Indonesia. This is an experimental research with quantitative approach. The subjects of the study were 60 kindergarten students in Surabaya. Data analysis technique used is Analysis of Variance (ANOVA).The results of this study indicate that habituation has an effect on self-awareness and prosocial behavior in children aged 4-5 years in the kindergarten students. Therefore, it can be concluded that the approach of habituation is very effective in instilling positive values into the students, so as to increase self-awareness and prosocial behavior.
\end{abstract}

\section{Keywords-Habituation, Self Awareness}

\section{INTRODUCTION}

Education in early childhood is a very important phase of the educational process, the arena in the early childhood phase is expected to develop and formulate the basics of personality, ability, thinking, intelligence, skill, and social skills. This is consistent with the main task of early childhood education that is preparing the personality, growth, maturity, and development of religious and moral values, so that children become people who have the knowledge and beliefs in God, have a noble character, healthy, intelligent, and cheerful. Early childhood education is a coaching effort aimed at children from birth up to the age of six that is done through the provision of educational stimuli to assist growth and physical and spiritual development so that children have readiness in entering further education (Ministry of education, 2012).

One aspect that plays an important role in early childhood development is emotional social. Emotional social development is expected to have the ability to recognize the environment, know nature, recognize the social environment, the role of society, and appreciate the social and cultural diversity that exists around the child and able to develop selfconcept, positive attitude toward learning, have self-control, good and have a sense of empathy on the problems of others (Yamin and Sanan, 2013).

An initial observation has been carried out by the authors at Khadijah Pandegiling Kindergarten, Surabaya on 20 children. The observation indicate that there are 10 children who have self-awareness especially in self-reliance in playing, child's confidence, and low-visibility discipline. The children were still dependent on the teacher in doing the activities, looking shy, and still difficult to follow the rules[13]. In prosocial behavior, 15 students also still found it difficult to adjust, difficult to help their friends, and the sense of empathy is still low.

Learning in kindergarten in developing self-awareness and prosocial behavior can be done through habituations that aim to develop their own ability and survival. Children are expected to be able to help themselves, self-aware of the potential they have. Self-awareness in question includes the awareness of who they are (who I am) and the awareness of self-potential (Purwaningsih, 2011).

According to Hera (2010), early age is one of the stages to develop social behavior that needs to be given the opportunity to play with friends. Age 2-6 years, children learn to social relationships and associate with people in the home environment, especially with children of the same age. They learn to adapt and work together in play activities. Further studies of children's groups show that social attitudes and behaviors that are formed at an early age are usually sedentary and have little change (Hurlock, 2006).

The results of research conducted by Suyahti (2013) which aimed at improving emotional social behavior capability through habituation activities to achieve optimal child development capability used several measurement indicators including the extend to which the student could: 1) carry out the task given by the teacher; 2) comply with applicable regulations; 3) take care of itself; 4) Install buttons and zippers themselves. Results in these studies proved an increase in emotional-social behavior skills in children by doing habituation activities.

The purpose of this study is to: 1) examine the influence of the habituation on self-awareness in early child aged 4-5 years in Khadijah Pandegiling Surabaya kindergarten; 2) examine the influence of habituation on prosocial behavior in early child aged 4-5 years in Khadijah Pandegiling Surabaya kindergarten; and 3) examine the influence of habituation on self-awareness and prosocial behavior in early child aged 4-5 years in Khadijah Pandegiling Surabaya kindergarten.

According to Arif (2002), habituation is a way that can be done to familiarize the students to think and act which is in accordance with the guidance of Islamic teachings. Habituation can be very effectively used to train good habits in early childhood. As the opinion of Fadillah and Khorida (2013), 
habituation is the cultivation of dexterity and saying something. In this regard, Mulyasa (2003) stated that habituation is the attitude that determines the human being as something privileged that can save power because it will become an inherent and spontaneous habit that the power can be used for various activities in every work and other activities.

According to Syah (2000:124), teaching habituation with the aim of improving students' attitudes and habits of new behavior become more precise and positive in the sense are aligned with the needs of space and time. In addition, according to Marimba (1999:82), the main purpose of habituation is the development of behavior as well as to say something so that the right ways can be mastered by learners. Mulyasa and Ispurwanti (2003:166), on the other hand, argue that the adoption of habituation is very effective when applied to younger learners because it has a record of very strong memories and immature personality conditions, so they are easily dissolved with the habits they do everyday. Therefore, as the beginning in the educational process, habituation is an effective way of inculcating moral values into the child's soul. The values embedded in the child will be manifested in the student's life since he/she stepped into adolescence and adulthood.

According to Stein and Howard (in Januarsari and Murtanto, 2003), self-awareness is the ability to recognize feelings and why a person feels that way and influences one's behavior toward others. These abilities include: the ability to convey clearly a person's thoughts and feelings, defend their self, and defend their opinions (assertiveness), the ability to direct and control their self and stand on their own feet (independence), the ability to recognize the strengths and weaknesses of the people and to enjoy oneself even when one has a weakness (self-esteem), as well as the ability to realize their potential and feel happy (satisfied) with the potential achieved (actualization). Meanwhile, social behavior is an activity related to other people, both peers, teachers, parents, and relatives (Mulyasa, 2014).

Prosocial behavior, as Baron (2006) states, is a beneficial act that benefits others without having to give direct benefit to the person doing such a relief, and may also risk the person. According to Batson (in Taylor, 2009), the prosocial behavior is a very broad category, which includes any action that helps or is designed to help others regardless of the helper's motives. It is also proposed that Kenrick (2010) prosocial behavior is an act of benefit to others which also applies when the helper has the goal of prosocial action: improving the welfare of each individual, raising social status, managing self-image, and managing the mood and emotion[15]. Damon (in Santrock, 2007) mentions that the prosocial behavior that develops in children is sharing and fair attitude. In line with Damon's statement (in Santrock, 2007), Santrock stated in his research results that prosocial behavior that develops in children include sharing, helping, and calming.

\section{METHOD}

This is an experimental research (quasi-experiment) with quantitative research methods. In the implementation, the researchers divided subjects of this research into two groups that have the same characteristics that consist of experimental groups and control groups[12]. The experimental group was given treatment with activity habituation, while the control group was not given treatment with habituation activities.

This research was conducted at Khadijah Pandegiling Kindergarten in the second semester of the academic year 2016-2017 in April - June 2017. This research involved 60 students, with 30 students in experiment class and 30 students in control class taken using a saturated sampling technique. The technique of data collection was carried out by using observation, documentation, and interview. The technique used to analyze data in this research is descriptive technique, validity and reliability test, and hypothesis test.

\section{RESULT AND DISCUSSION}

The summary of $\mathrm{F}$ score from table 1 shows that the average score self-awwereness of the experimental class was greater than the control class. It can be concluded that there was the influence of the class that is treated with habituation that is not given the treatment of habituation on selfawwereness in children aged 4-5 years at the time of pre-test. The post-test $\mathrm{F}$ test is known that the average score of selfawwereness of the experimental class is greater than the control class at the time after being treated (posttest). It can be concluded that there is the influence of class which is given a treatment of habituation with unadjusted treatment to selfawwereness at child age 4-5 years at post-test.

TABLE I. THE INFLUENCE OF HABITUATION ON SELFAWARENESS

\begin{tabular}{|c|c|c|c|c|}
\hline Test & Class & $\begin{array}{c}\text { Average } \\
\text { score of self- } \\
\text { awareness }\end{array}$ & F & Sig. \\
\hline \multirow{2}{*}{ Pre Test } & Experiment & 2.6097 & \multirow{2}{*}{19.776} & 0,000 \\
\cline { 2 - 3 } & Control & 2.3251 & & \\
\hline Post Test & Experiment & 3.2553 & 776.38 & 0,000 \\
\cline { 2 - 3 } & Control & 2.6720 & & \\
\hline
\end{tabular}

(Source: anova test on self awareness)

The results showed that there was an effect treated with habituation with the unfamiliar treatment of self-awareness in children aged 4-5 years. This is evidenced by the difference in the average score of self-awareness between classes treated with habituation and who were not given habituation treatment. At the time after being treated (posttest), self-awareness in the experimental and control classes has different mean values. The average score of self-awareness of students who were treated with habituation was greater than the self-awareness of students who were not given the treatment of habituation. This means the influence of the treatment of habituation is very large on the formation of self-awareness of students. Habit, according to Mulyasa (2003), is an attitude that determines the human being as a privilege that can save power, because it will become an inherent and spontaneous habit that the power can be used for various activities in every work and other activities. Habituation can be very effectively used to train good habits in early childhood. Habituation can shape students' selfawareness, namely the ability to recognize feelings and why one feels that way and the influence of one's behavior toward others (Stein and Howard in Januarsari and Murtanto (2003)). 
There is a significant difference between self-awareness score of the experimental class and the control class in posttest. The experimental class is a class treated with habituation, while the control class is a class that did not use habituation treatment. Post-test self-awareness in the experimental class and control class has a different mean value after being treated habitually. The average score of self-awareness with behavioral habituation is able to attract students' attention to make learning meaningful. Arif (2002:110) argues that as a beginning in the educational process, habituation is an effective way of inculcating moral values into the child's soul. The values embedded in them will then be manifested in their lives since they begin to move into adolescence and adulthood. Therefore, the habitual approach is very effective in instilling positive values into the learners.

TABLE II. THE INFLUENCE OF HABITUATION ON PROSOCIAL BEHAVIOR

\begin{tabular}{|c|c|c|c|c|}
\hline Test & Class & $\begin{array}{c}\text { Average } \\
\text { score of } \\
\text { prosocial } \\
\text { behavior }\end{array}$ & F & Sig. \\
\hline Pre Test & Experiment & 25425 & 10.312 & 0.002 \\
\cline { 2 - 3 } & Control & 23907 & & 0.000 \\
\hline Post Test & Experiment & 32105 & 460.1038 & \\
\cline { 2 - 3 } & Control & 24647 & & \\
\hline
\end{tabular}

(Source: anova test on self awareness)

Summary of F test pre-test is known that the mean of the prosocial behavior of experiment class is bigger than control class. It can be concluded that there is an effect of habituation without being treated habitually to prosocial behavior in children aged 4-5 years. The result of Post-test $F$ test is known that the mean of the prosocial behavior of experiment class is bigger compared to the control class at the time after being treated (posttest). It can be concluded that there is an effect of habituation that is not given the treatment of habit of prosocial behavior in children aged 4-5 years at post-test.

The results showed that there was the influence of the class treated with habituation with the unfamiliar treatment of prosocial behavior in children aged $4-5$ years; this is evidenced by the difference in the mean score of prosocial behavior between classes treated with habituation that was not given habituation treatment. At the time after being treated (posttest), prosocial behavior in the experimental and control classes has different mean values. The average prosocial behavior treated with habituation is greater than the prosocial behavior students who were not given habituation treatment. This means that the influence of the treatment of habituation is very large on the formation of student prosocial behavior. According to Fadillah and Khalida (2013:177), by performing routine habits every day, students will do by themselves consciously without any coercion. By direct habituation, the children have been taught the discipline in performing and completing an activity. This is due to the habit of repetition.

According to Baron (2006), prosocial behavior as a helpful act, that benefits others without having to provide a direct benefit to the person doing such aids, and perhaps even risking the person helping. If a student is already used to socialize with the surrounding community then the student will have an action to help others regardless of the helper's motives. The results of this study support the results of research from Siti Rahmah (2015) which proved that the method of sociodrama could improve prosocial behavior in children aged 5- years in early childhood.

TABLE III. INFLUENCE TREATMENT HABITUATION ON SELF-AWARENESS AND PROSOCIAL BEHAVIOR

\begin{tabular}{|l|l|c|c|}
\hline \multirow{2}{*}{} & \multicolumn{2}{|c|}{ Sig. } \\
\cline { 3 - 4 } & Pre-test & Post Test \\
\hline \multirow{4}{*}{ Groups } & Pilla"is Trace & 0.000 & 0.000 \\
\cline { 2 - 4 } & Wik's Lambda & 0.000 & 0.000 \\
\cline { 2 - 4 } & Hotelling"s Trace & 0.000 & 0.000 \\
\cline { 2 - 4 } & Roy's Largest Root & 0.000 & 0.000 \\
\hline
\end{tabular}

(Source: multivariate test)

Based on the above table, the Sig value which was tested by Pillar's test procedure, Wilk's Lambda, Hotelling's Trace and Roy's Largest Root all showed 0.000 for pretest and 0.000 for posttest. Thus, because Sig $<0.05$ then Ho is rejected, which means there is a difference between experiment group and control groups on self-awareness and prosocial behavior. This means that self-awareness and prosocial behavior is influenced by the treatment of habituation.

TABLE IV. TEST OF BETWEEN SUBJECTS EFFECTS

\begin{tabular}{|c|c|c|}
\hline & Effect & Sig. \\
\hline groups & Self-awareness (pretest) & 0.000 \\
\hline & $\begin{array}{c}\text { Prosocial behavior } \\
\text { (pretest) }\end{array}$ & 0.002 \\
\hline & $\begin{array}{c}\text { Self-awareness } \\
\text { (posttest) }\end{array}$ & 0.000 \\
\hline & Prosocial (posttest) & 0.000 \\
\hline
\end{tabular}

Self-awareness and prosocial behavior variable of pre-test show the sig value of 0.000 for self-awareness and 0.002 for prosocial behavior. It means self-awareness and prosocial behavior shows the difference between control and experiment group because it shows the value of Sig. below 0.05 meaning that self-awareness and prosocial behavior are influenced by the treatment of habituation.

Regarding the concept of numbers and science, the post-test shows the sig value of each is 0.000 , which means selfawareness and prosocial behavior show the difference between the control group and the experiment because it shows the value of Sig. below 0.05 . Thus, it means self-awareness and prosocial behavior are influenced by the treatment of habituation.

\section{CONCLUSION}

The authors conclude that habituation has an influence on self-awareness in children aged 4-5 years in Khadijah Pandegiling Surabaya kindergarten. This is evidenced by the difference in the average score of self-awareness between classes treated with and without habituation treatment, where the average self-awareness of students who were treated with habituation was greater than the self-awareness of students who 
were not given the treatment of habitation. Also, habituation has an influence on prosocial behavior in children aged 4-5 years in Khadijah Pandegiling Surabaya kindergarten. This is evidenced by the difference in the mean score of prosocial behavior between classes treated by habituation and those who are not given habituation treatment, where the average prosocial behavior students treated by habituation was greater than the prosocial behavior students who were not given the treatment of habituation. Finally, habituation has also an influence on self-awareness and prosocial behavior in children aged 4-5 years in Khadijah Pandegiling Surabaya kindergarten, meaning that together there is influence between classes treated with habituation (experiment) with unadjusted treatment (control) to self-awareness and prosocial behavior or in other words self-awareness and prosocial behavior are influenced by the use of habituation treatment.

\section{REFERENCES}

[1] Baron, RA, \& Byrne, D, \& Branscombe, NR .2006.Social. Psychology, Mc Graw Hill, New York.

[2] Fadillah, M, \& Khorida, LM .2013. Pendidikan Karakter Anak Usia Dini, Ar-Ruzz Media, Jogjakarta.

[3] Hera, ML.2010. Pendidikan Anak SD, Universitas Terbuka, Jakarta.
[4] Hurlock, BE .1978. Perkembangan Anak, Erlangga, Jakarta.

[5] Hurlock, BE .2006. Psikologi Perkembangan, Erlangga, Jakar-ta.

[6] Januarsari, TR, \& Murtanto, Y.2003, Ledakan EQ, Kaifa, Bandung.

[7] Kemendikbud .2012. Dokumen Kurikulum .2013.Kemendikbud, Jakarta.

[8] Mulyasa, A .2003. Kurikulum Berbasis Kompetensi, Remaja Rosdakarya, Bandung.

[9] Mulyasa, E, \& Ispurwanti, D.2003. Manajemen Pendidikan Karakter, Erlangga, Jakarta.

[10] Santrock, JW .2007. Perkembangan Anak, Kencana, Jakarta.

[11] Santrock, JW .2007. Psikologi Pendidikan, Kencana, Jakarta.

[12] Avolio, Bruce J., et al. 2009. A meta-analytic review of leadership impact research: Experimental and quasi-experimental studies. The Leadership Quarterly 20.5. PP 764-784.

[13] Mills, A. (2009, August 3). Early-childhood education takes to the outdoors. Edutopia. Retrieved from:http://www.edutopia.org/earlychildhood-outdoor-education-waldkindergarten.

[14] Paci, Sophie, and Elizabeth Carroll. "Outside the Walls: Exploring the Benefits of Outdoor-Based Learning for Children's Development.

[15] Williams, M. (2007). Building genuine trust through interpersonal emotion management: A threat regulation model of trust and collaboration across boundaries. Academy of Management Review, 32(2), 595-621. 